\title{
Teaching NeuroImage: Dorsal Medullary Lesions in Juvenile-Onset Alexander Disease
}

John Sollee, BS, and Amy Waldman, MD, MSCE

Neurology ${ }^{\circledR}$ 2021;97:e2050-e2051. doi:10.1212/WNL.0000000000012411

Figure Dorsal Medullary Lesions in Alexander Disease

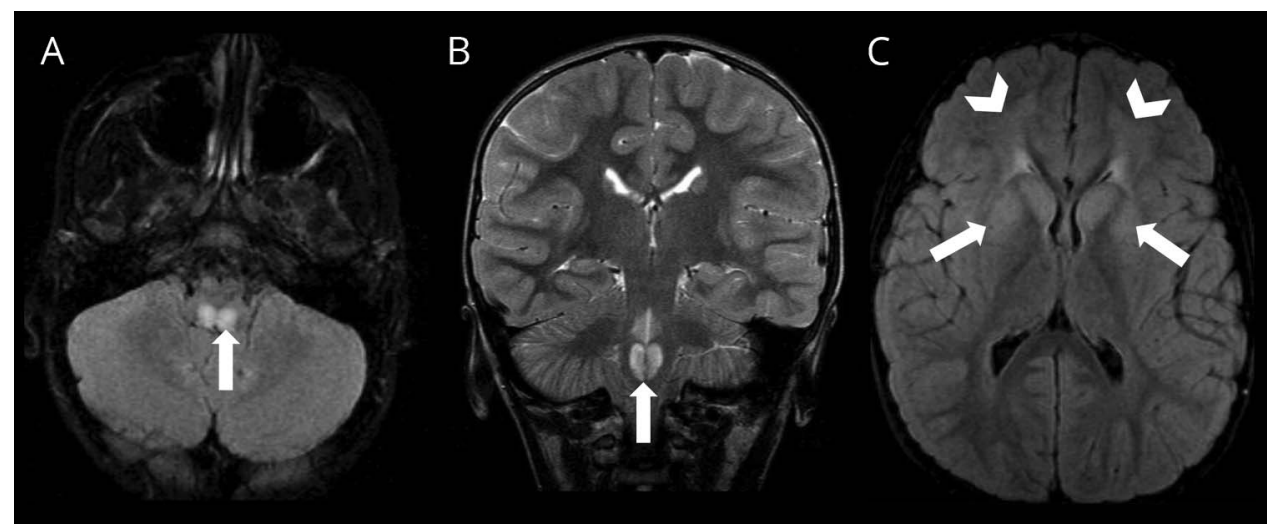

Brain MRI in Alexander disease reveals distinctive hyperintense bilateral dorsal medullary lesions on (A) axial FLAIR and (B) coronal T2-weighted images in a heart-shaped appearance. (C) Additional diagnostic criteria (T2 hyperintense signal abnormality in the frontal white matter [arrow heads] and basal ganglia [arrows]) are present on axial FLAIR images. ${ }^{1}$

A 6-year-old boy presented with dysphagia, vomiting, and weight loss. Early developmental milestones were notable for mild gross motor and speech delay. Hypotonia was present on examination. Brain MRI revealed bilateral enhancing dorsal medullary lesions (figure, contrast not shown). The differential diagnosis included a leukodystrophy or mitochondrial disease. Alexander disease was confirmed genetically (de novo variant in GFAP-targeted testing: p.Arg376-Gly). Typical features also include hypernasal speech with subsequent motor difficulties and autonomic dysfunction over time. ${ }^{2}$ GFAP sequencing should be considered in patients with unilateral or bilateral dorsal medullary lesions with localizing symptoms (e.g., vomiting and dysphagia).

\section{Study Funding}

The authors report no targeted funding.

\section{Disclosures}

J. Sollee reports no disclosures relevant to the manuscript. A. Waldman reports no disclosures relevant to the manuscript. Go to Neurology.org/ $\mathrm{N}$ for full disclosures.

\section{Correspondence}

Dr. Waldman

waldman@chop.edu

\section{MORE ONLINE}

Teaching slides

links.lww.com/WNL/

B454

From the Division of Neurology (J.S., A.W.), Children's Hospital of Philadelphia, PA; Warren Alpert Medical School of Brown University (J.S.), Providence, RI; and Departments of Neurology and Pediatrics (A.W.), Perelman School of Medicine at the University of Pennsylvania, Philadelphia.

Go to Neurology.org/N for full disclosures. 


\begin{tabular}{lll}
\hline \multicolumn{2}{l}{ Appendix } & Authors \\
\hline Name & Location & \\
\hline $\begin{array}{l}\text { John Sollee, } \\
\text { BS }\end{array}$ & $\begin{array}{l}\text { Warren Alpert Medical School } \\
\text { of Brown University, } \\
\text { Providence, RI }\end{array}$ & $\begin{array}{l}\text { Drafting/revision of the } \\
\text { manuscript for content, } \\
\text { including medical writing for } \\
\text { content; major role in the } \\
\text { acquisition of data; study } \\
\text { concept or design; and } \\
\text { analysis or interpretation of } \\
\text { data }\end{array}$ \\
\hline $\begin{array}{l}\text { Amy } \\
\text { Waldman, } \\
\text { MD, MSCE }\end{array}$ & $\begin{array}{l}\text { Division of Neurology, } \\
\text { Children's Hospital of } \\
\text { Philadelphia, PA }\end{array}$ & $\begin{array}{l}\text { Drafting/revision of the } \\
\text { manuscript for content, } \\
\text { including medical writing for } \\
\text { content; major role in the } \\
\text { acquisition of data; study } \\
\text { concept or design; and } \\
\text { analysis or interpretation of } \\
\text { data }\end{array}$ \\
\hline
\end{tabular}

\section{References}

1. Van der Knaap M, Naidu S, Breiter S. et al. Alexander disease: diagnosis with MR imaging. Am J Neuroradiol. 2001:22(3);541-552.

2. Srivastava S, Waldman A, Naidu S. Alexander disease. In: Adam MP, Ardinger HH, Pagon RA, Wallace SE, editors. GeneReviews. University of Washington, Seattle; 19932020. Updated November 12, 2020. https://www.ncbi.nlm.nih.gov/books/ NBK1172/ 


\title{
Neurology
}

\section{Teaching NeuroImage: Dorsal Medullary Lesions in Juvenile-Onset Alexander Disease John Sollee and Amy Waldman}

Neurology 2021;97;e2050-e2051 Published Online before print June 22, 2021

DOI 10.1212/WNL.0000000000012411

This information is current as of June 22, 2021

\author{
Updated Information \& \\ Services \\ including high resolution figures, can be found at: \\ http://n.neurology.org/content/97/20/e2050.full \\ References \\ This article cites 1 articles, 1 of which you can access for free at: \\ http://n.neurology.org/content/97/20/e2050.full\#ref-list-1 \\ Subspecialty Collections \\ This article, along with others on similar topics, appears in the \\ following collection(s): \\ All Pediatric \\ http://n.neurology.org/cgi/collection/all_pediatric \\ Leukodystrophies \\ http://n.neurology.org/cgi/collection/leukodystrophies \\ MRI \\ http://n.neurology.org/cgi/collection/mri \\ Permissions \& Licensing \\ Information about reproducing this article in parts (figures,tables) or in \\ its entirety can be found online at: \\ http://www.neurology.org/about/about_the_journal\#permissions \\ Reprints \\ Information about ordering reprints can be found online: \\ http://n.neurology.org/subscribers/advertise
}

Neurology ${ }^{\circledR}$ is the official journal of the American Academy of Neurology. Published continuously since 1951, it is now a weekly with 48 issues per year. Copyright @ 2021 American Academy of Neurology. All rights reserved. Print ISSN: 0028-3878. Online ISSN: 1526-632X.

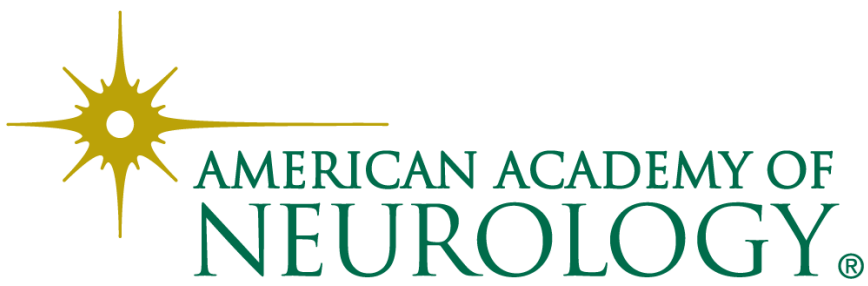

